\title{
New Frontiers, New Actors, New Rules: Global Commons, Human Rights, Business. How to Improve Judicial Cooperation and International Development
}

\author{
Cristiana Carletti \\ Laura Guercio
}

\section{Abstract}

The state of international relations and the effort of international public actors and non-state entities to adopt new rules to govern their relationships by balancing human rights protection, human development and economic business growth is at stake. The creation of new legal frameworks to introduce innovative concepts and to regulate the interaction among traditional and innovative actors is not an easy task: it demands from States and International Organizations a proper determination and patience to preserve original legal features while advancing different notions and operational tools to found special regimes and disciplines which could be mutually and complementary reinforcing. The contribution aims at debating legal concepts, different stakeholders, renewed procedures that have emerged in the global scenario and that need for appropriate and applicable international rules for a challenging governance.

Keywords: global commons; business; development; human rights; judicial cooperation

\section{Introduction}

\section{Global commons: for a (consolidated?) definition of the concept}

The term 'global commons' is inherently connected with the legal notion of the governance upon all the areas and resources that are placed beyond the sovereignty of the State and not subject to the national jurisdiction of a certain State.

Its meaning is intended to extend the exercise of the governance in a shared perspective, i.e. to assign to the international community as a whole the control over these areas and to preserve the freedom of access and the use of the resources contained therein for the benefit of all peoples.

Traditionally the 'commons' were identified with resources held in common and jointly exploited by a local community, assumed that all the members have equal property rights in that respect and could exploit these resources to gain proper 
economic advantages. All the decisions about this resources' domain, composed of common pool resources, must be adopted by the aforementioned members, avoiding any exclusive property title on them.

By refining the original meaning, the 'commons' have been referred to the material notion of 'goods': the obligation to control and to protect the property as well as all the benefits descending from its use and exploitation could be associated only with territorial accessible areas and resources.

In translating the concept from the national to the international setting the struggle among States to expand their power and to exercise their jurisdiction in areas beyond their sovereignty was at the core of the elaboration of the best doctrine on the idea of mare liberum of Grotius.

The principle that lies behind the Grotius idea on mare liberum consists of an original legal distinction among the categories of no one property (res nullius), of the common possession (res communis) and of the public/State property (res publica). Beyond this categorization, the freedom of access to the sea and the exploitation of its resources to gain benefit for all peoples is the key element to create a new classification including the common properties whereas no specific property law is in force: in these circumstances the natural law governs the management of things that are shared in a community without any kind of sovereignty over natural resources. According to Grotius reasoning, at the beginning the concept of common property avoids any form of physical delimitation or boundary as well as any contractual rules providing for trade exchange following the exploitation of common resources. Afterwards, through their shared use and the possibility to put them at risk of unfitting or over-exploitation, the common property concept has encompassed a further distinction: from one side the occupation title could not be applied on areas that cannot be the property of individual or collective owners; on the other side common resources are naturally be put under the property of one owner but, at the same time, could benefit also other persons and all users are required to preserve them so far granting access for all those ones who potentially are in conditions to use them.

The common property category proposed by Grotius might be exemplified by referring to the existence of a twofold component: the natural use and the public utility of the resource, respectively by and in favour of the community and its members. If we apply this doctrine to the international legal system, as Grotius has done in his times, we could mention several samples of common properties such as the outer space or the high seas: the impossibility to be susceptible of occupation, their adaptability in terms of access and exploitation, their common use for producing benefits to all peoples confirm us the rightness of Grotius idea of categorization also in the contemporary global scenario. 
Indeed the inoccupation of these areas by nature or on grounds of public utility has led to significant paths of exploration and to the drafting and adoption of common rules - rectius special international regimes - excluding any right of public or private ownership beyond the national jurisdictions.

Conversely the Grotius doctrine has informed the elaboration of extensive regulations to oblige namely public actors - States and International Organizations - to not claim any property right but to protect natural resources in the abovementioned areas: the increasing number of potential users putting at risk the preservation of common goods and resources has not been translated into strict norms negatively impacting on the access and the use of such areas but into a renewed meaning of the concept of 'global commons' supporting the principle of freedom of access and use but also of highly protection of the resources contained therein.

As above reminded also the economic and trade component has reflected new necessities of global users in respect of the proper sustainable use of common resources. In other terms national and international policies in the field of the environment could not be defined and implemented autonomously from economic and trade planning. This has been an essential precondition to promote the drafting of international legal standards and instruments taking into account multiple factors, so far excluding any property right claim but also recalling that all natural resources are part of the humankind heritage both in current and future times and that all members of the international community are recommended to put their particular interests aside and to promote the preservation of commons at their best.

If we try to apply this consideration to the original Grotius doctrine, it's true that the principle of the mare liberum and of all similar areas beyond national jurisdictions has proved to be critically accomplished in respect of complementary but opposing factors. Outer spaces and planets, high seas, polar regions have a proper legal nature of global commons: it is out of questioning. So far the impracticality to exercise an effective control over these territories entails the unfeasibility to claim any kind of jurisdiction on them. Nevertheless, due to relevant technological improvements as for scientific research in such areas, their access and use has been inspired by the principle of 'first come, first served': this meant and means at present that the global commons could not be considered as totally 'free' areas. Even if industrialised and technologically advanced countries and well as private actors which invest in this field could take a great advantage in accessing and exploiting the resources in these areas, however new rules governing international cooperation and special legal regimes for the protection of natural wealth and resources beyond the limits of national jurisdictions have been sponsored by developing countries. These rules have surely updated the Grotius doctrine and have provided for a renewed meaning of the global commons in the current global scenario.

Moving from this consideration, it's evident that the traditional definition of the concept of 'global commons' is partially consolidated. Apart from the global natural 
asset, the environmental and economic functions performed by some commons in favour of all peoples are undoubtable and have informed the drafting or the reelaboration of international legal standards to be translated and implemented at the national level by States. The results could be simplified by mentioning the following general legal categories: natural resources fully under the national jurisdiction of one State; natural resources shared by two or more States; natural resources located beyond the limits of national jurisdictions, i.e. in international areas so out of any State control.

As for the third category, we can assume that 'global commons' could be included in, also attempting to review the Grotius idea by introducing the principle of the common property to testing new legal features, rights and duties on behalf of public and private actors in the global scenario. The linkage with human rights of individuals and peoples to reinforce the judicial cooperation to prevent and to punish violations and to support new development cooperation lines is the natural consequence of the application of the Grotius approach in contemporary times.

\section{Human rights generations: evolution and doubts}

Before analyzing the specific subject of this work, some considerations on the theory of human rights generations are necessary.

Generational classifications of human rights are currently legion in international legal scholarship: institutions, judges and scholars specialise in them and invoke them continuously. Less common are explanations of what actually is meant when we speak of human rights in generational terms.

The division of human rights into generations, initially proposed in 1979 by Karel Vasak, provided firstly the following classification: the first generation concerns civil and political rights, enshrined in the International Covenant on Civil and Political Rights (ICCPR); the second generation concerns economic, social and cultural rights, specifically those enshrined in the International Covenant on Economic, Social and Cultural Rights (ICESCR); and finally, the third generation, reflected in different specific instruments, mainly General Assembly declarations, refers to what Vasak called 'solidarity rights', which include the right to development, the right of selfdetermination, minority rights, the right to peace and the right to ownership of the common heritage of mankind (Vasak 1977). More recently, the proposal has also been made to add a fourth generation of human rights comprising the rights connected with information technology and the right to sustainable development of the future generations. According to the universally recognized principle of social equity the future generations are entitled to find at their birth a friendly environment and sufficient resources for development.

This classification raises some considerations. Certainly no denies the predetermined rights. The question does not involve them, but their classification. Without going into the deep analysis of this theory, on which scholars have already widely written, there 
are some questions that deserve reflection. Is "generation" accurate when describing categories of human rights? Do 'generations' refer to temporal differences regarding the rise of different human rights in international law? Or do they refer to the opportunity that certain kinds of rights can have a prior protection over other kinds of rights? But basically, the main questions concern the opportunity of this description: is the term "generation" accurate when describing categories of human rights? Is understanding human rights in international law in terms of generations historically, chronological or analytical correct?

On an historical approach, Vasak himself describes that the generational conception of human rights came into existence in different 'waves' throughout history. The first wave, which accompanied the French revolution, gave rise to the generation of civil and political rights. With the second wave, after the Russian revolution of 1917, economic, social and cultural rights gained universal recognition. The third wave accompanied 'the emancipation of colonised and dominated peoples' in the middle of the 20th century. Other scholars consider different events to describe the generational waves (Headley 2008, Moyn 2010, Hoffmann 2010, Martines 2012).

Some doubts emerge on the generational theory based on an historical approach. Recalling events prior to the 20th century to classify a chronology of international human rights confuses the origins with their legal existence, as the historic chronology of human rights generations does not correspond to the history of human rights in international law. But this consideration does not exclude the possibility of a chronological account of their international legal status.

Human rights received formal expression in 1948, with the adoption of the Universal Declaration of Human Rights (UDHR) which is not only a list of human rights: even if questioned by some no western countries, it is the first legal complete recognition of the inherent human dignity and of the equal and inalienable rights of all individuals. It enshrines civil and political rights at the same time as the social, economic and cultural rights, rendering suspect the claim that first-generation rights chronologically preceded second-generation and, also, third generation rights. As Fausto Pocar quotes, in the context of UDHR "the rights of the so-called first and second generations are expressly and simultaneously listed in the document, while the so called third generation rights, although not expressly described in a detailed text, may largely, and perhaps entirely, find their recognition under the general provision in Article 28. This Article states that "everyone is entitled to a social and international order in which the rights and freedoms set forth in this Declaration can be fully realized" (Pocar 2015).

One comes to the same conclusions sharing the positivistic idea, underlined by Patrick Macklem, that human rights first appeared in international law in 1976, when the ICCPR and the ICESCR entered into force. Even in this case, as the Scholar quotes, a chronological explanation of the three classes of rights is erroneous. First and secondgenerations of human rights received international legal existence simultaneously 
also with some of the rights of third generation (Macklem 2015): for example, the right of self-determination, considered of third generation, was formally recognised as a human right by the International Court of Justice just one year before the two Covenants came into force (Western Sahara (Advisory Opinion) ICJ Reports (1975).

The result is that however accurate such chronological descriptions of human rights may be, they fail in the description of a sequential generation of human rights.

Even if one considers the human rights generations as analytical instead of chronological categories, some doubts remain. Vasak himself distinguishes a human right connected to a particular generation of rights because of distinctive properties that it possesses, specifically in terms of the obligations they generate and on whom their obligations fall. He considers civil and political rights "as their respect requires that the state do nothing to interfere with individual liberties" (Vasak 1977). Social, economic and cultural rights, in contrast, require "positive action by the state to be implemented" (ibidem). Unlike first and second generation rights, third-generation rights, because they "reflect a certain conception of community life, ... can only be implemented by the combined efforts of everyone: individuals, states and other bodies, as well as public and private institutions'" (ibidem).

Contrary to this analytical division between positive and negative rights, all rightscivil, political, social or economic-give rise to both positive and negative State obligations to protect certain interests and not others. Also, the so-called thirdgeneration rights have negative and positive dimensions: for example, the right to development imposes internal negative and positive obligations on States. Another way of understanding generations in analytical terms is to highlight a conceptual sequencing of types of human rights: that means that civil and political rights can be thought of as conceptually prior to social and economic rights, because civil and political rights establish the legal and political standing of those entitled to exercise and enjoy social and economic rights. But also this explanation risks to fail: social and economic rights can just as easily be comprehended as conceptually prior to civil and political rights: these last rights are practically meaningless if a person cannot satisfy his or her most basic needs in life.

Then, in conclusion, is it appropriate to talk about human rights generations? There is no doubt that different human rights seek to protect different kinds of interests that require different means of protection. In such a sense, a categorization of human rights makes sense. But a generational classification of them, whether chronological or analytical, risks to fail to appreciate what is common to all human rights in international law: their common nature and their common purpose. Understanding classes of rights as conceptual sequences must confront a foundational commitment in international human rights law to the concept of indivisibility that first explicitly surfaced in the Proclamation of Tehran in the International Conference on Human Rights held on 22 April-13 May 1968. Indivisibility, interdependency and interrelatedness of human rights is beyond argument. As an umbrella concept, 
indivisibility advocates that the realisation of each right is necessary to the realisation of all others for the final common purpose to mitigate injustices. For this reason, civil and political rights, social, economic and cultural rights, as well those thought of as third-generations or, currently, also fourth- generation rights, comprise but one a single population of rights, dialoguing with the structure and operation of international law.

\section{For a revitalisation of the debate about new actors on the global setting: public and private stakeholders along the international legal perspective}

The global setting has always seen States as key actors that are called to debate, draft and adopt international standards and rules to implement policies and measures impacting on their domestic legal frameworks.

The original state-centric perspective has been made more complex and dynamic in terms of global governance when non-state actors have appeared on the scene: this has had a great impact on the identification of common features or, conversely, on the opportunity to change models and forms of institutionalized settings and practices to be adapted to the newcomers.

In this context two issues need to be explored that have informed the recent revitalisation of the debate about the relationship between state and non-state actors: the different legal nature of private actors and their role and activities within the international framework in compliance with standards and rules in force; the nature of the relationship between public and private actors in defining and adopting new forms of joint governance to protect human rights and to promote the human development at large.

About the first point under consideration the compression of the role of States and International Organizations in rules' drafting through an appropriate use of their technical knowledge and the availability of financial resources has called for complex and hard regulatory issues entailing the involvement of non-state actors. Indeed the challenge of the global regulation has encompassed not a State capitulation but a reassertion of public actors in rule-making and decision-making: institutional authorities have decided to impose renewed rules upon private actors when both have common interests to be accomplished; alternatively they have proposed to private actors to work together to gain the same goal but also achieving proper comparative advantages.

In both cases a good compromise that could satisfy public and private actors is to create a joint or hybrid governance model, whose main features are: the clarity about roles and gaming rules, the procedural transparency and the opportunity to broaden the number of partners involved in the rule-making process. This model is based on the complementarity of functions ascribed to public and private actors: the first ones are requested to define some relevant criteria and ad hoc details for drafting rules and facilitating their full implementation at the national and international level; the 
latter ones have a supporting role in providing key services as far as the compliance at national and local level, the real legitimacy of the institutional governance, some logistic and financial assistance to enable the rule-making process.

The power of private rule-makers could be expanded over times: they are very close to peoples' preferences which could strongly influence the contents of key policies and at the same time they are able to perceive if these preferences are favourable also for their proper economic interests. On a general note, it's often true that private rulemakers have a longstanding technical knowledge and experience that could help in planning medium and long term policies and measures: but they must be confronted with public actors to fully understand the regulatory setting in force and to propose potential amendments to ensure a stronger compliance with international legal standards. Meanwhile the opportunity to support the rule-making process but also to be included as direct recipients of the legal results, i.e. national and international standards and rules, could be noticed as a robust limitation for the activities of private actors on the global scene. This increasing legal return could also encompass new competitors which have diverging interests from the private actors supporting the rule-making process and that hope to be part of the process itself as supporters.

For the last reason private stakeholders involved in such processes must always take into account to strengthen their power and influence as well as their technical knowledge to impact on their rulemaking capability in relation to institutional and public actors. This means for them: to be enough aware about the dynamicity of the international scenario and of international standards and rules as translated and implemented in national legal frameworks; to know which are the vulnerabilities and the practical limitations of the public capabilities to let private actors to expand their role and support; and to have clear ideas about the challenge of matching the private rule-making with public policy goals.

If we deserve our attention on potential renewed relationships between International Organizations and private actors, it is clear that political, social and economic changes have pushed for a new approach: it is based again on the failure of the traditional state-centric model, also within the proper International Organization scheme, so far encouraging private actors to be more evident and to interact with the IOs membership in a different manner.

Since the launch in June 2000 of the UN Global Compact, private actors - in this case business companies - have dealt with significant challenges in order to align their strategic priorities and working mechanisms with the ten universal principles contained therein and aimed at improving politically and operationally the cooperation between the UN Member States and private partners.

Following this first occasional contact, the public-private dialogue has been pursued and increased in a more coordinated manner with concrete double efforts from both sides. There have been several reasons for achieving this common aim: the global 
dimension of business and, so far, the role of business companies in defining new criteria and parameters for reinforcing the IOs global governance; the financial availability of private actors and the potentiality of increased investments in keydevelopment sectors; the respect of international standards and principles, such as corporate sustainability performance and operational transparency.

Moreover the IO has linked non-traditional financial issues with market potential of business companies in the environmental, social and governance domains, so far aiming at finding valuable private partners for exploring new international partnership opportunities. This approach has covered also the drafting of new dialogue models, calling private actors for their experiences in the field of fundraising, for the evaluation and adaption of international soft law standards to IOs membership, for improving due diligence and integrity measures within the IOs framework, for a concrete structural engagement with the private sector at large.

Along the aforementioned considerations the basics of parallel interactions among States, International Organizations and private actors are driven by a dynamic interplay of political, economic and institutional changes concerning these three players on the global scene. If the first two ones have partially changed their operational approach while always working for the achievement of economic and social progress and development both at the bilateral and multilateral level, the latter ones have been the most exposed to test their capabilities vis-à-vis the key-issues of the current global agenda, i.e. environmental protection, human rights, social inclusion and good governance.

If we focus now on the nature of the relationship between public and private actors, the conceptual viewpoint is that the relationship between public (States and International Organizations) and private actors is merely described as public-private partnership (PPP). But the terminology needs to be explored and adapted to several contexts.

Apart from theoretical categories of possible relationships which assign to public and private actors codified and hierarchical roles such as "private self-governance in the shadow of hierarchy", "delegation to private actors", "co-governance of public and private actors" and "consultation and co-option of private actors", we could find some guiding principles that inform the PPP.

Firstly the engagement of private actors should be driven by public actors in a coherent, enabling and empowering manner; secondly it should be inspired by a concrete realism about common opportunities and benefits, assumed that both public and private actors are equally motivated and committed to responsible practices being encouraged through successful partnerships; thirdly, private actors should move from a cloistered original business approach to more strategic and transformational attitudes for building an effective PPP. 
Furthermore the PPP should be based on a common understanding of at least two key values: respect and support. Public and private actors are requested to not harm and to not abide international legal standards. At the same time they are called to define shared opportunities for action, collaboration and mutual engagement, by identifying risks and negative impacts and provide for practical solutions. Above all, due to global political and economic openness, PPPs should pursue the common goal of serving the public good: this means that, if it's true that public and private goals are intrinsically overlapped, the classic global issues are interrelated with business and this demands for co-power, co-responsibility, co-adaptation of strategies and operations, exploring the potential of the PPP.

To leverage this advantage and to unlock the functionality of the PPP, a new template for networked public-private governance could be explored to achieve greater stability, stronger cooperation, higher protection of human rights, effective environmental safeguarding, concrete rule of law and good governance. The template could be tabled by translating some rules of the private governance into the global public setting, without attempting to traditional governing principles of the State but responding to the challenges of the globalization and to different categories of actors and rules to be composed in a multi-actoral and multi-sectoral framework. This template proposal should also encompass a new kind of communication among concerned actors, inspired by common formal rules beyond traditional boundaries. In other terms the template will try to solve typical problems of public and private actors within their specifically defined and functionally distinct frameworks and could be considered as a new model of coordinated meta-governance for better performing of the PPP.

Within the political and economic global arena this will promote different opportunities to renovate the potential of the public-private relations and partnerships.

The core of this common route will depend upon a mix of institutional networking to find innovative forms of state and non-state actors governance through: rule-making and global agenda setting; political challenges and trends along the lines of an inventive multilateralism based on an extended engagement of private actors; economic and trade developments as a field where cooperation with the private sector could be positively explored and encouraged in compliance with corporate social responsibility standards.

The institutional and political engagement of private actors has been represented by the permanent dialogue with traditional actors at the international level in order to mobilize the contribution of business to support the achievement of global public policies' goals.

This led to a sort of legitimacy of private actors to reflect over the opportunity to regulate their activities through the rules in force for States and International 
Organizations: even if the contribution from business companies to draft a legal binding instruments covering the issue of monitoring and assessment of human rights international compliance is at present an on-going process, the idea to build a soft law consensual conceptual framework addressed to all the above mentioned categories to drive them for the application of human rights standards has been translated into the elaboration and adoption in 2011 of the UN Guiding Principles on Business and Human Rights.

The demand for a targeted action to deal with broader economic and trade challenges has been another setting to test the capabilities of the private actors: greater investments as well as the establishment of global value chains worldwide required governmental support well beyond traditional geographic boundaries and entered into a global public domain which falls under the double competence of States and International Organizations, ranging from education and health to trade investments and environmental policies. Such conditions have called for differentiated but complementary responsibilities on behalf of States, International Organizations and private actors/business companies-transnational corporations: they are requested to act in compliance with corporate sustainability and responsibility principles whenever they operate individually or jointly at the international, national, and local level. If they do not miss to work transparently and grant full access to information, the disclosure approach on governance, social and environmental issues will pave the way for a fruitful and constructive engagement in both easy and difficult settings to deal with challenging issues such as child labour, gender equality, climate adaptation, water scarcity, corruption. In this way the sharing of universal principles and common values is evidently the right cooperative methodology to gain long-term results to be assessed in financial, social, environmental and ethical terms.

\section{The business model and action within the multilateral framework}

Before going forward on the analysis of the subject of this work, it seems necessary to dwell on a question: does the current business model fit with the existing multilateral framework that is supposed to develop an equal economic system?

Founders of the post-war international economic system knew the importance of multilateralism. They had all experienced the enormous cost of individual actions taken outside a multilateral framework in the 1930s. Governments, struggling to offset the impact of the Great Depression, adopted measures that were designed to export their problems but that could only succeed if other countries did not take similar measures. Then, it was clear that if trade and capital flows take place on a multilateral framework, economy enhances efficiency and increases competition. It was understood that the multilateral track is fairer given that it encompasses a wide diversity of strong and weak, big and small, economies: it provides a stable and predictable environment to a maximum number of operators. It is more resilient because it is organized to deliver what is expected from a regulatory system: negotiate the rules; monitor their implementation; and settle disputes when they arise. 
Since then, the international economy has prospered over the past few years. World real GDP has grown and the world is a far more affluent place than it was a half century ago: living standards, measured by indicators such as life expectancy, infant mortality, nutritional status, and literacy, have all improved. But, beneath the surface, there are causes for concern. There are three major, related factors that give rise to worry. The first one is the increased reliance on preferential arrangements, with their implied discrimination. The second is that private capital flows do not yet fall into any coherent multilateral regime. The third is the increasing tendency, for individual countries, to place emphasis on their own position vis-à-vis the system without considering how outcomes may weaken the institutional underpinning and the international governance of the current multiculturalism framework. These three aspects risk to contrast an equal worldwide economic development in a multilateral framework, where multilateralism is, as Robert Keohane defines, "the practice of coordinating national policies in groups of more states" (Keohane 1990). The consequence is that some parts of the world continue to fail to share in the gains.

These problems need to be addressed by enforcing legal instruments and international institutions inside a multilateral system.

Since the 1947 creation of the General Agreement on Tariffs and Trade (GATT), which in 1994 was converted into the World Trade Organization (WTO), the number of member countries has grown to exceed 160. This illustrates that the there is an international interest for building international trading rules along the multilateral track.

But still some of the rules of trade remain unbalanced against developing countries. This is not the place to analyze all the economic imbalances in the world. What is important is to underline that some current principles of the multilateral system have to be readjusted in order to factor in the new strength of emerging countries. Some of the WTO disciplines remain too weak to properly level the playing field in an international economy which has globalized rapidly in recent decades, subsidies being a case in point. The relative importance of obstacles to trade is changing because of factors such as e-commerce and non-tariff measures.

To address these various weaknesses and to consolidate the multilateral system, one should launch a major initiative to update the multilateral rules book and modernize the organization that should include a thorough review of the basic principle that has underpinned the WTO - the reciprocity between developed countries and "special and differential treatment" in favor of poorer countries: whereas this principle made sense a few decades ago, the emergence of major developing countries, starting with China, has created a new "in- between" class, which needs to be recognized and organized.

We see a pressing need for greatly expanded support for a well-defined set of global public goods where the multilateralism institutions, and particularly the World Bank, 
should be contributing given their sectoral and financial capabilities: climate change, agriculture, health, and data relevant for development policies and programs. With greater global integration, developing countries face increasing risks over which they have little or no control, and which no one country, rich or poor, has the incentive to tackle alone.

The World Bank is particularly well suited for raising and deploying financing models of development-at the political level in raising and acting as a reliable conduit for resources, and at the technical level in setting priorities for use of those resources and their allocation across needs. It does so in a spirit of cooperation with other international institutions as WHO, FAO, Green Climate Fund, and the regional Banks, especially in supporting the provision of regional public goods.

But it is clear that it is not sufficient without a long term agenda involving the responsibility of all countries. Global leaders have set ambitious social, economic and environmental goals in the form of the 2030 Agenda for Sustainable Development, the Paris Climate Agreement, and subsequent the Organisation for Economic Cooperation and Development (OECD) and G20 commitments in favor of open trade and investment.

Specifically, the OECD has developed deep knowledge on the value of trade through its analytical work, especially on Global Value Chains (GVCs), Trade in Value-Added (TiVA), and the Services Trade Restrictiveness Index (STRI). Its support will be essential in developing a renewed understanding of the benefits of trade and foreign direct investment (FDI). Trade is often blamed for negative impacts in national economies, due to the lack of flanking policies to support competitiveness and flexibility. In this sense, towards the 24th Conference of the Parties (COP24) in December 2018, the OECD is supposed to facilitate an exchange on market-oriented, cost-effective and competition enhancing national strategies for member countries.

Also, the OECD will be an important agent to further mobilize private sector support for the SDGs which come in to force on 1 January 2016 after being adopted by world leaders in September 2015 at an historic UN Summit. Over the next fifteen years, with these new goals that universally apply to all, countries will mobilize efforts to end all forms of poverty, fight inequalities and tackle climate change, while ensuring that no one is left behind. For a company, 17 goals and 169 targets can seem intimidating but companies need to be seriously addressing those goals and targets that are material to their business and where they have the biggest impact.

Business is moving fast on the implementation of the Sustainable Development Goals (SDGs). Many businesses are actively incorporating the SDG framework into their business models and reporting. This is because the SDGs not only identify where we have to be in 2030 to create a sustainable world: they also consider new markets and opportunities for companies all over the world, turning the global goals into local business. 


\section{International and national legal compliance: the access to remedy and the challenges of the judicial cooperation}

Business enterprises can be easily involved with human rights abuse. Businesses can affect the entire spectrum of internationally recognised human rights - civil and political rights, as well as economic, social and cultural rights - for example, workers' rights, the right to privacy, equality and non-discrimination, freedom of expression and the right to health. It can depend to the virtue of their activities and to their negative impacts on the social life. Although causing human rights abuse is considered a crime in most of the domestic jurisdictions, business enterprises are seldom the subject of law enforcement and criminal sanctions: yet private claims often fail to proceed to judgment and, where a legal remedy is obtained, it frequently does not meet the international standard of "adequate, effective and prompt reparation for harm suffered", according to the Basic Principles and Guidelines on the Right to a Remedy and Reparation for Victims of Gross Violations of International Human Rights Law and Serious Violations of International Humanitarian Law (adopted by General Assembly resolution 60/147, Article I.2 (b) and VII), and to international human rights law that stipulates the right to a fair trial and the right to an effective remedy - i.e. Article 8 of the Universal Declaration of Human Rights, Article 2 (3) of the International Covenant on Civil and Political Rights (ICCPR), Articles 6 and 13 of the European Convention on Human Rights (ECHR). Also European law provides, under Article 47 of the Charter, for access to justice, including legal aid to ensure that access is effective, when Member States act within the scope of EU law.

Subsequent interpretations have stressed the importance of making remedies accessible to persons in situations of vulnerability, such as Article 13 of the Convention on the Rights of Persons with Disabilities (CRPD) and the General Comments by the monitoring mechanism for the International Covenant on Economic, Social and Cultural Rights (ICESCR).

There are different means of achieving accountability and access to remedy in cases of business-related human rights abuses, including State-based non-judicial mechanisms and non-State complaint mechanisms, such as operational level grievance mechanisms. But among them, effective State-based judicial mechanisms "are at the core of ensuring access to remedy", as the 2011 UN Guiding Principles on Business and Human Rights, Implementing the United Nations "Protect, Respect and Remedy" Framework (A/HRC/17/31) quote in Principle 27. The obligations of States with respect to this right have been reflected in the Guiding Principles on Business and Human Rights: Implementing the Protect, Respect and Remedy Framework in terms of a "State duty to protect" against business-related human rights abuses.

The question is that those seeking to use judicial mechanisms to obtain a remedy face persistent problems common to many jurisdictions: fragmented, poorly designed or incomplete legal regimes; lack of legal development; structural complexities within 
business enterprises; problems in gaining access to sufficient funding for private law claims. This situation is particularly acute in cases involving gross human rights abuses and other particularly serious offenses - such as slavery, torture, extra-judicial killings, forced and child labour, and large-scale harm to human health and livelihoods. Companies can be involved either as offenders or by being complicit in such abuses.

The challenges of how to secure accountability and access to remedy for victims of business-related human rights are exacerbated in cross-border cases that have been put at the core of a renewed public and global discussion.

That is due also to the structure of business companies.

Business enterprises can take many legal and structural forms: they may be single corporate entities or a group of companies working together through relationships on the basis of shared ownership, or contract. According to the company law doctrine of "separate corporate personality", recognized in most jurisdictions, each company has a separate existence from its owners. Consequently, a company, a parent company, that owns shares in another subsidiary company will not generally be legally responsible for acts, omissions or liabilities of that subsidiary merely on the basis of the shareholding. In other words the legal liability for human rights abuses of a subsidiary's activities may not extend beyond the subsidiary itself.

The structure of business companies is not the only obstacle to an easy access to judicial remedies against human rights violations. While many domestic legal regimes focus primarily on within-territory business activities and impacts, the realities of global supply chains, cross-border trade, investment, communications and movement of people are placing new demands on domestic legal regimes. Cross-border cases pose particular challenges that can undermine effective cooperation: these challenges include a lack of information about how to make a request to agencies in other States, a lack of opportunities for cross-border consultation and coordination; a lack of resources needed to process requests in a timely manner; a lack of awareness of investigative standards in other States. The main question is the lack of clarity across jurisdictions about the roles and responsibilities of different interested States in cross-border cases create a significant risk that no action will be taken, leaving victims with no prospect of remedy.

Rectifying these deficiencies require concerted and multifaceted efforts from all States, including actions relating to law reform, law enforcement, and closer international cooperation. For this reasons, it is relevant to consider a range of bilateral and multilateral arrangements to support, facilitate and enable international cooperation with respect to legal assistance and enforcement of judgments in crossborder cases. States should work for both "vertical" and "horizontal" policy coherence in the development of laws and policies on business and human rights. 
To elaborate further the responsibility of business to respect human rights, a number of instruments have been developed.

At the international level, the Office of the UN High Commissioner for Human Rights (OHCHR) has provided additional guidance and interpretative instruments, the Council of Europe has issued recommendations, the International Labour Organization (ILO), the Organisation for Economic Co-operation and Development (OECD) and the International Organization for Standardization (ISO) have also contributed significantly in establishing instruments and mechanisms related to business and human rights.

At the national level, the interlink between businesses and human rights has also received greater attention, with action plans, guidance and legislation aimed at mitigating any negative impact of business on human rights - or even stimulating positive impact.

Basically, two instruments are relevant. As already mentioned, the 2011 UN Guiding Principles is the first global framework that exclusively addresses business-related human rights abuses. Although not legally binding, they enjoy serve as a basis for policy approaches towards business and human rights; the 2016 Council of Europe Recommendation on human rights and business includes a particular focus on access to remedy. These instruments emphasize the importance of access to remedy in cases of business-related human rights abuse.

Besides the UN Guiding Principles, OHCHR issued in 2016 a comprehensive guidance dealing in particular with access to remedy, called the OHCHR Accountability and Remedy Project, the 2016 UN Guidance. This guidance concretely advises on which tools work well to implement the UN Guiding Principles.

Besides, according to the Recommendations of the 2016 OHCHR Report (A7HRC/32/19) "Member States should: (a) As part of their implementation of the "Access to remedy" pillar of the Guiding Principles, consider undertaking a review of the coverage and effectiveness of their domestic law regimes that regulate the respect by business enterprises of human rights, using the guidance in the annex to the present report as a starting point, with a view to (i) developing policies and legal reforms that respond more effectively to the practicalities of organization and management of business enterprises and which take into account the particular challenges arising from complex global supply chains; and (ii) improving the effectiveness of State-based judicial mechanisms as a means of delivering corporate accountability and remedy in cases of business-related human rights abuses; (b) Develop a comprehensive strategy for implementation of the guidance in a manner that responds appropriately to local legal structures, challenges and needs, for instance, as part of national action plans on business and human rights, and/or as part of strategies to improve access to justice generally; (c) Take steps, using the guidance, to improve the effectiveness of crossborder cooperation between State agencies and 
judicial bodies, with respect to both public and private law enforcement of domestic legal regimes".

\section{Business and human rights: how to cope with bad practices to improve the protection of human rights, the contribution of environmental human rights defenders}

The promotion and protection of human rights is at present a global commitment assumed by all relevant public and private stakeholders. Also the civil society at the collective and individual level is actively involved to ensure its contribution to support the respect of human rights: a peculiar role is attributed to individuals who spare no efforts to defend human rights by raising their voices and bringing the issue to the attention of all national and international public and private actors.

Apart from a partial international definition of human rights defenders, the most relevant reference to introduce this special category of 'private' actors is contained in the UNGA Declaration adopted by Resolution 53/144 of December 9 1998, titled "Declaration on the Right and Responsibility of Individuals, Groups and Organs of Society to Promote and Protect Universally Recognized Human Rights and Fundamental Freedoms": its Art. 1 mentions the individual or collective element to identify the human rights defender as the actor who promotes and fights for the protection and the enjoyment of human rights and fundamental freedoms at the national and international level.

Giving legitimacy to the work of human rights defenders on the global scene has been a fundamental step for their status and for the recognition of the concrete impact of their actions.

The attempt to categorize human rights defenders is based only on the common intent to put their life at risk for the protection and promotion of human rights, to prevent violations and to call for global responsibilities of public and private actors whenever a human rights violation is reported. These individuals indeed could be: lawyers who look for ensuring that human rights violations are properly prosecuted; journalists who denounce governmental authorities or military personnel as the main responsible for ordering or committing crimes against peoples, vulnerable categories, minorities; healthcare personnel in charge for assisting victims of every form of illtreatment, violence and torture and for witnessing for them against the offenders and perpetrators in order to be brought in front of judicial authorities; trade unionists and indigenous groups.

The efforts of human rights defenders in making aware the public opinion about human rights violations could for sure put at risk their personal freedom and wellbeing as well as that one of their families: in every part of the world they have been perceived as illegitimate combatants for the cause of human rights and this has put them in critical conditions to be threatened, arbitrarily arrested, expelled, defamed or 
accused of being responsible for individual or collective fuelling aimed at carrying out subversive activities, mentally and physically tortured or even murdered.

For these reasons in several intergovernmental international and regional systems the role and action of human rights defenders has been legitimised, in order to protect their personal safety and to recognise their valuable contribution for the protection and promotion of human rights.

Within the UN framework in 2000 the Commission on Human Rights issued a proper mandate for the appointment of a Special Procedure on the situation of human rights defenders. This mandate was extended in 2008 by the Human Rights Council and at present the Special Rapporteur exercise this role by seeking, receiving and examining all information reports on the critical working conditions of human rights defenders worldwide; the mandate-holder has also the competence to dialogue with public and private actors to ensure the implementation of the contents of the above mentioned Declaration; he/she reports annually to the UN system and provides for targeted recommendations for improving the situation of human right defenders within international and national contexts under attention, also monitoring their follow-up by public and private stakeholders. The annual reporting is also an occasion to further detail specific topics or relevant issues concerning the promotion and protection of human rights defenders that, in the opinion of the mandate-holder, need to be explored according to thematic or country priorities and related concerns.

Also in other intergovernmental systems, such as the Council of Europe and the OSCE, the same approach has been adopted in terms of reinforcement of legal and operational mechanisms and measures to ensure that human rights defenders could safely carry out their ordinary work.

Apart from such systems, the role and action of human rights defenders has been promoted by the governmental authorities of concerned States: the public support to individuals who put their life at risk for strengthening human rights protection has strongly impacted on the global public opinion, making peoples aware about their courage and the relevance of their voluntary initiatives.

To this purpose the UN Special Rapporteur on the situation of human rights defenders has promoted an interesting debate over business and human rights. In his opinion business actors have different but complementary responsibilities if compared with States and International Organizations, depending upon their legitimacy and the subsequent compliance with hard and soft laws, i.e. international treaties, guiding principles and codes of conduct, common practices and operational features. He has proposed the following categories of actions to be expected from business actors within a multifaceted international legal framework.

The first category is composed of legal obligations on behalf of business actors, similarly reproducing the contents of the 2011 UN Guiding Principles on business and human rights as well as some provisions contained in the human rights international 
core treaties. These legal obligations refer directly to the protection of human rights defenders and strongly recommend business actors to refrain from or to be complicit in ordering or carrying out physical or moral attacks against human rights defenders, so far compressing their basic rights and freedoms, such as opinion, information and expression, association and assembly. The second category encompasses legal obligations contained in the above mentioned UN Guiding Principles and aimed at facilitating an active engagement, consultation and involvement of human rights defenders and those individuals and groups who demand to be appropriately defended: the common aim of this process consists of designing, implementing, assessing and evaluating cooperation interventions carried out by business actors in favour of beneficiaries. Along these circumstances, on an equal foot with concerned public actors, business actors should apply due diligence and monitor the full respect of human rights during and at the completion of the field intervention. The third category looks forward an ordinary business practice based on a permanent dialogue and advisory mutual exchange of information and support between business actors and human rights defenders: in this situation business actors could act by providing direct technical and financial assistance to human rights defenders working individually or in close cooperation with local organizations and associations, otherwise could encourage institutional actors to provide for open and fruitful conversations to reinforce the legal and operational framework to consult, respect and protect human rights defenders. As for the latter action, the multiple advisory national mechanisms involving both business actors and human rights defenders interacting with governmental authorities in designing the contents of the National Plans of Action on business and human rights has proved to be an efficient tool to gain the respect for this kind of obligation. Lastly, the fourth category demands business actors to be actively involved in advocating and seeking remedy for human rights defenders whose rights and freedoms have been totally or partially compressed by domestic laws and policies. The obligation could be performed in relation to unique public occasions where the business actor supports openly a human rights defender through a statement addressed to concerned governmental authorities and to the public opinion. But it could also be embodied by business actors as influential supporters in respect of the institutional domestic stakeholders to reinforce their legislative framework and their judiciary mechanism to facilitate the access to remedy and to provide for appropriate redress and compensation for human rights defenders and direct victims of human rights violations. In this sense human rights defenders could play a significant role in order to create partnership opportunities with business actors and to foster simultaneously their collaboration with public and private actors.

In one of the most recent report submitted to the UNGA in 2015 the Special Rapporteur has introduced an overview about the critical relationship between human rights defenders and business in relation to human rights violations particularly in the environmental context. 
The Special Rapporteur refers to the defender within a predetermined vulnerable context where multiple political, economic and social factors impact negatively on its role, personal dignity and freedom of movement, freedom of expression and opinion through communication channels. At the same time each attitude or action putting the defender at risk often goes unpunished.

The Special Rapporteur also reports an alarming aspect about human rights defenders working to detect the respect of corporate social responsibility principles by business companies: the complicity between States and business companies for partially ensuring high legal standards, so far letting business activities unpunished when they violate human rights. The Special Rapporteur has adopted specific recommendations on this point that are addressed to States (asking for an effective protection of human rights defenders and for facilitating their advice in the compilation of National Plans of Action and in cooperative interventions) and to business companies (to encourage human rights defenders activities and to protect their freedom of expression and assembly).

In another recent report released in 2016 the Special Rapporteur has examined the environmental human rights defenders conditions in relation to business.

In his view environmental human rights defenders need for specific legal and institutional safeguards, jointly with the respect and support from business companies.

For this reason the Special Rapporteur assigns to States the obligation to protect directly environmental human rights defenders as representatives of the civil society, being further empowered as actors within the 2030 Agenda for Sustainable Development. They have the right to life, personal liberty and security, freedom of expression, freedom of peaceful assembly, right to privacy, as enshrined in the Universal Declaration of Human Rights, the International Covenant on civil and political rights and in the abovementioned 1989 Declaration. In other terms States have the duty to respect these rights as well as to act in order to prevent and repress all violations of human rights of environmental defenders, facilitating their access to remedy and compensation.

At the same time the Special Rapporteur assigns to States the obligation to protect indirectly when the violation has been committed by public or private business companies in relation to UNGPs. He stresses the need for an enhanced domestic legislation and real participation of environmental human rights defenders to joint planning and decision-making processes to ensure the full protection of their human rights. Whenever the violation has been already recorded, the environmental human rights defenders safeguard and the support in accessing remedial judicial and nonjudicial mechanisms should be granted: this is crucial especially when they are not familiar with remedies or have difficulties in accessing due to the blurring legal nature 
of the violation and the related accountability on business companies/multinational corporations.

In the final section of the report the Special Rapporteur makes relevant recommendations to concerned actors while aiming to aware the public opinion about the role of environmental human rights defenders and stigmatizing violations of their rights by States and business companies.

States are recommended to adopt a human rights based approach for the economic development, strengthening the participation of non-institutional stakeholders to the compilation of strategies and NAPs on business and human rights. They are further requested to ensure the functioning of investigation and remedial mechanisms to punish the offenders violating environmental defenders human rights.

Business companies are recommended to respect national legal obligations - soft laws and ethical international norms - promoting the dialogue with environmental human rights defenders, granting them access to data and information, avoiding any conduct and actions putting the defenders at risk, and providing for the establishment and functioning of non-judicial remedial mechanisms.

\section{Conclusions}

The contemporary debate on new frontiers, new actors and new rules moving from a re-conceptualization of the global commons in relation to international human rights standards and the role of business at large encompasses great challenges for improving traditional judicial and development cooperation mechanisms and procedures.

We are facing a transformation of the global governance in its essence: it is out fo doubst that it demands for fresh and additional commitments from all concerned actors in performing international relations, in amending existing laws and in promoting global economic opportunities. In this scenario they are requested to clarify their role and contribution for common goals and shared working methodologies. The comparison and possible convergences and divergencies among legal international and national frameworks are a good starting point: differently from global constitutionalism and global administrative law, global governance is broad enough to include different but complementary competing contributions from both public and private actors.

It means that the global governance is a really dynamic setting, that could be periodically reinvented but that must be based on the strong and comprehensive support of business, in order to grant the access and the protection of global commons for all and to ensure the full respect of human rights and fundamental freedoms of individuals and peoples worldwide. 


\section{References}

[1] Andonova L. (2010), Public-Private Partnerships for the Earth: Politics and Patterns of Hybrid Authority in the Multilateral System, in Global Environmental Politics, Vol. 10, N. 1, Pp. 25-53

[2] Borzel T., Risse T. (2005), Public-Private Partnerships: Effective and Legitimate Tools of International Governance?, in Grande E., Pauly L. (Eds.), Complex Sovereignty: on the Reconstitution of Political Authority in the 21st Century. Toronto: University of Toronto Press, Pp. 195-216.

[3] Buck S.J. (1998), the Global Commons. An Introduction, Island Press

[4] Feenstra R. (2009), Hugo Grotius Mare Liberum 1609-2009. Original Latin and English Translation. Leiden: Brill.

[5] Headley J.M. (2008), the Europeanization of the World. Princeton: Princeton University Press

[6] Hoffmann S.-L. (2010), Introduction, in Hoffmann S.-L. (Ed.), Human Rights in the Twentieth Century. Cambridge: Cambridge University Press

[7] Kell G. (2016), Relations with the Private Sector, in Cogan J.K.-Hurd I.Johnstone I. (Eds.), the Oxford Handbook of International Organizations. Oxford: Oxford University Press, Pp. 730-753

[8] Keohane R.O. (1990), Multilateralism. An Agenda for Research, in International Journal, Vol. 45, N. 4, Pp. 731-764

[9] Macklem P. (2015), Human Rights in International Law: Three Generations or One?, in London Review of International Law, Vol. 3, N. 1, Pp. 61-92

[10] Martinez J.S. (2012), the Slave Trade and the Origins of International Human Rights Law. Oxford: Oxford University Press

[11] Mattli W. (2016), Private Transnational Governance, in Cogan J.K.-Hurd I.Johnstone I. (Eds.), the Oxford Handbook of International Organizations. Oxford: Oxford University Press, Pp. 171-188

[12] Moyn S. (2010), the Last Utopia: Human Rights in History. Harvard: Harvard University Press

[13] Pocar F. (2015), Some Thoughts on the Universal Declaration of Human Rights and the Generations of Human Rights, in Intercultural Human Rights Law Review, Vol. 10, N. 3, Pp. 43-53

[14] Schrijver N., Prislan V. (2009), from Mare Liberum to the Global Commons: Building on the Grotian Heritage, Grotiana, Vol. 30, N. 1, Pp. 168-206

[15] Sending O.J., Neumann I.B. (2006), Governance to Governmentality: Analyzing Ngos, States, and Power, in International Studies Quarterly, Vol. 50, N. 3, Pp. 651-672

[16] Vasak K. (1977), a 30-Year Struggle, Unesco Courier

[17] Wijkman M. (1982), Managing the Global Commons, in International Organization, Vol. 36, N. 3, Pp. 511-536 